\title{
Occurrence of Gnathotrichus materiarius (Fitch, 1858) (Coleoptera, Curculionidae, Scolytinae) in South-Western Poland
}

\author{
Andrzej Mazur ${ }^{1} \bowtie$, Radosław Witkowski ${ }^{1}$, Jarosław Góral ${ }^{2}$, Grzegorz Rogowski ${ }^{2}$ \\ ${ }^{1}$ Poznań University of Life Sciences, Faculty of Forestry, Department of Forest Entomology, Wojska Polskiego 71C, \\ 60-625 Poznań, Poland; e-mail: andrzej.mazur@up.poznan.pl \\ ${ }^{2}$ Forest Protection Service, The State Forest National Holding, Grunwaldzka 90, 50-001 Wrocław, Poland
}

\section{Abstract}

Gnathotrichus materiarius is listed as an alien ambrosia beetle in European fauna. This is an invasive species from North America, which was found in Europe (France) in the 1930s. In Poland, it was recorded in 2015. Already in 2017 numerous infestations of G. materiarius on lying Pinus sylvestris wood were obsereved. G. materairius is a xylomycophagous species and wood damage to its feeding is similar to that caused by striped ambrosia beetle Trypodendron lineatum. The paper presents sites of G. materairius occurrence found in 2016 and 2017. These include 15 sites located in managed forests ( 5 forest districts) as well as in 2 national parks situated along south-western border of Poland. G. materairius beetles were found in pheromone-baited traps used to monitor Ips duplicatus and I. amitinus or collected from infested Scots pine wood. The paper presents the description and characteristics of wood damage due to G. materiarius as well as its distinguishing features.

\section{KeY WORDS}

distribution, Poland, ambrosia beetles, technical damage to wood, Gnathotrichus materiarius, insect pest

\section{INTRODUCTION}

The genus Gnathotrichus includes 16 species of bark beetles (Scolytinae) that belong to the Corthylini tribe, naturally inhabiting both American continents (Wood 1982; Bark Beetle... 2011). All Gnathotrichus species are xylomycetophagous insects (ambrosia mycetobionts) that inhabit coniferous wood. They excavate galleries in infested wood, and form specific relationship with symbiotic fungi, which constitute food for larvae and adults.
Gnathotrichus materiarius (Fitch 1858) is a native species in North America and the Antilles (Wood 1982; Wood and Bright 1992). The beetle was brought to Western Europe (France) in the 1930s (Balachowsky 1949) and ever since has been gradually spreading to the east, reaching Scandinavia (Sweden, Finland: Gillerfors 1988; Valkama et al. 1998), central Europe (Germany, Austria, Switzerland, Poland, the Czech Republic: Schedl 1980; Hirschheydt 1992; Knížek 2009; Witkowski et al. 2016) and southern Europe (Spain, Italy, Slovenia: Faccoli 1998; Jurc et al. 2012). 
In Poland, G. materiarius specimens were recorded in 2015 (Witkowski et al. 2016), however, it was earlier assumed that the incidence of this species in Poland was quite possible (Mokrzycki et al. 2011; Grodzki and Mokrzycki 2014). Presently, G. materiarius is unquestionably enlisted in Polish fauna registers (Wanat and Mokrzycki 2018).

The aim of the present study was to describe the most recent sites of $G$. materiarius occurrence and to determine its range in south-western Poland, as well as to depict this beetle morphological features that will enable to diagnose the presence of $G$. materiarius in wood.

\section{MATERIAL AND METHODS}

G. materiarius ambrosia beetles were found in pheromone-baited traps used for monitoring populations of bark beetles feeding on Norway spruce (Ips duplicatus and Ips amitinus), mounted in selected forests managed by the Regional Directorate of State Forests in Wrocław, and also in forests of the National Parks: Karkonoski and Stołowe Mts. There were used Theysohn slit traps baited with Ecolure ID ${ }^{\circledR}$ (Ips duplicatus) and Amitinuswit $\AA$ (Ips amitinus) (Otto et al. 2016; Mazur et al. 2017).

Wood infested by $G$. materiarius was recorded in August 2017 in the Forest District Węgliniec. Then piled pine wood from the trees cut down at the beginning of the growing season was inspected in the neighboring forest districts. Infested wood was found in the Forest Districts Ruszów and Pieńsk. The inspections were carried out in August and September 2017, and included search for ambrosia beetles in wood, their entry holes as well the galleries in surface wood layers. Scots pine wood (2.4-meter long $\log$, with the diameter of $18 \mathrm{~cm}$ ) was collected in the Forest District Ruszów (comp. 567f) and transported to the laboratory for rearing $G$. materiarius under controlled conditions. The log was cut into sections, and other beetles and small invertebrates accompanying the studied ambrosia beetle were deterred using the Tullgren apparatus. It allowed to receive the infor- mation about the density of wood infestation and the sex ratio of $G$. materiarius beetles staying in wood during autumn and winter.

Measurements of gallery diameters and lengths were made with a caliper with an accuracy of $0.01 \mathrm{~mm}$. The ambrosia beetles were measured using a Nikon SMZ 1500 stereomicroscope with Eclipsenet software, enabling metric measurements of the microscopic image.

Scaning photos were prepared with use of Hitashi S-3000N scanning electron microscope, and before taking the photos, microscope slides were coated with gold and palladium. The evidence materials are stored in the collection of the Department of Forest Entomology, Poznań University of Life Sciences.

\section{Results AND discussion}

Analyzes of beetles species composition caught in pheromone traps and examinations of wood confirmed the presence of G. materiarius at 15 sites (Tab. 1, Fig. 1).

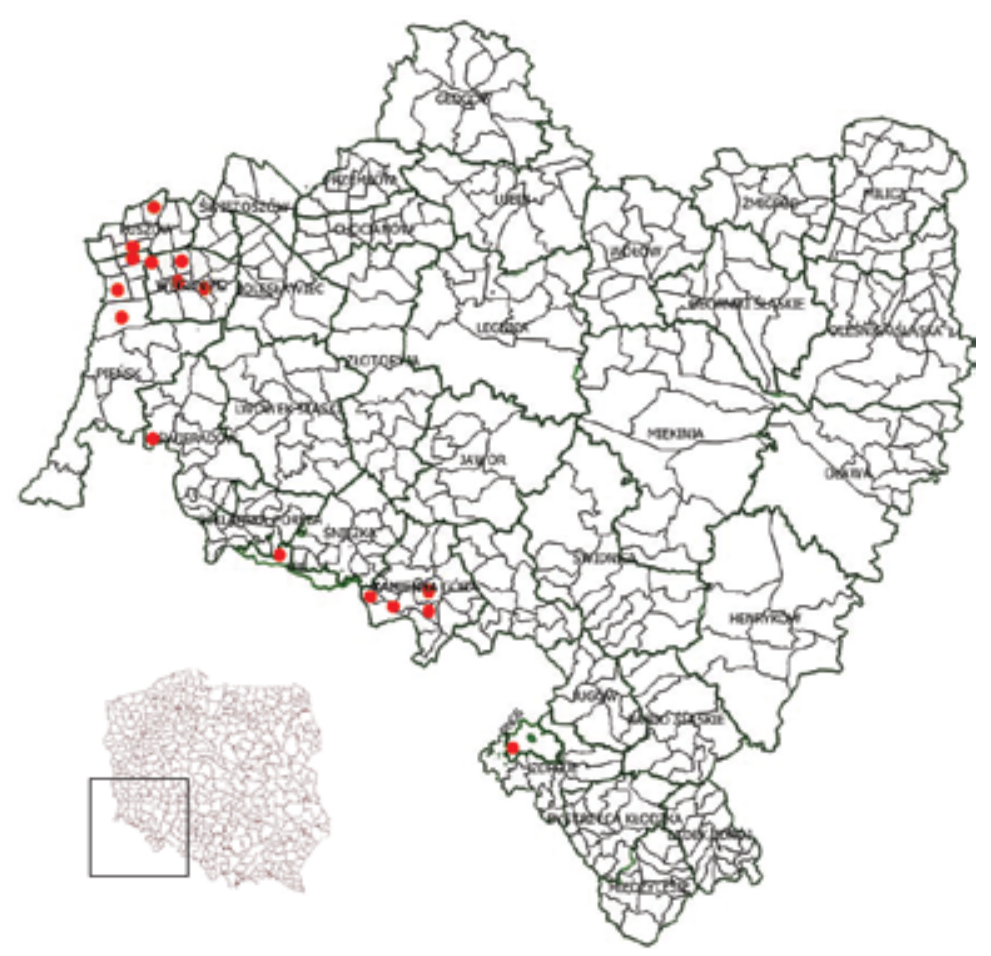

Figure 1. Localizations of Gnathotrichus materiarius occurrence in southwestern Poland (based on pheromone trap catches and observations in 2016-2017) 
Table 1. List of Gnathotrichus materiarius localizations in south-western Poland (based on pheromone trap catches and observations in 2016-2017)

\begin{tabular}{|c|c|c|c|c|}
\hline $\begin{array}{c}\text { Locality } \\
\text { (Forest District, Sub-district, Compartment, Altitude }\end{array}$ & $\begin{array}{c}\text { Date of } \\
\text { collection/ } \\
\text { observation }\end{array}$ & $\begin{array}{l}\text { Number of } \\
\text { specimens }\end{array}$ & $\begin{array}{c}\text { Geographical } \\
\text { coordinates }\end{array}$ & $\begin{array}{l}\text { Method } \\
\text { used* }\end{array}$ \\
\hline $\begin{array}{l}\text { Forest District Kamienna Góra, Forest Sub-District Marciszów, comp. 41d } \\
(400 \mathrm{~m} \text { a.s.1.) }\end{array}$ & 5.06 .2017 & 1 & $\begin{array}{l}16,0003 \\
50,7989\end{array}$ & A \\
\hline $\begin{array}{l}\text { Forest District Kamienna Góra, Forest Sub-District Klatka, comp. } 214 \mathrm{~h} \\
\text { (1000 m a.s.l.) }\end{array}$ & 22.05 .2017 & 1 & $\begin{array}{l}15,8414 \\
50,7246\end{array}$ & A \\
\hline $\begin{array}{l}\text { Forest District Kamienna Góra, Forest Sub-District Szarocin, comp. 148a } \\
\text { (600 m a.s.l.) }\end{array}$ & 8.05 .2017 & 1 & $\begin{array}{l}15,9362 \\
50,7605\end{array}$ & A \\
\hline $\begin{array}{l}\text { Forest District Kamienna Góra, Forest Sub-District Ogorzelec, comp.165f } \\
\text { (800 m a.s.l.) }\end{array}$ & 10.06 .2016 & 1 & $\begin{array}{l}15,8754 \\
50,7492\end{array}$ & A \\
\hline $\begin{array}{l}\text { Forest District Świeradów, Forest Sub-District Przylesie, } \\
\text { comp. 340d (380 m a.s.1.) }\end{array}$ & $\begin{array}{l}22.05 .2017 \\
31.07 .2017\end{array}$ & $\begin{array}{l}1 \\
1\end{array}$ & $\begin{array}{l}15,2164 \\
50,9985\end{array}$ & A \\
\hline $\begin{array}{l}\text { The Stołowe Mts. National Park, Protected Area Bukowina, comp.130n, } \\
\text { ( } 580 \text { m a.s.l.) }\end{array}$ & 5.06 .2017 & 3 & $\begin{array}{l}16,2884 \\
50,4502\end{array}$ & A \\
\hline $\begin{array}{l}\text { Karkonoski National Park, Protected Area Przełęcz, comp.147a } \\
(980 \text { m a.s.l.) }\end{array}$ & 5.06 .2017 & 2 & $\begin{array}{l}15,5864 \\
50,7976\end{array}$ & A \\
\hline $\begin{array}{l}\text { Forest District Wegliniec, Forest Sub-District Krucze Gniazdo, comp.217f, } \\
\text { 224d, (approx. } 200 \text { m a.s.1.) }\end{array}$ & 19.09 .2017 & $>1$ & $\begin{array}{l}15,2860 \\
51,2858\end{array}$ & B \\
\hline $\begin{array}{l}\text { Forest District Węgliniec, Forest Sub-District Czerna } \\
\text { comp. 420b, (approx. } 200 \mathrm{~m} \text { a.s.1.) }\end{array}$ & 19.09 .2017 & $>1$ & $\begin{array}{l}15,3992 \\
51,3024\end{array}$ & B \\
\hline $\begin{array}{l}\text { Forest District Węgliniec, Forest Sub-District Ołobok } \\
\text { comp. } 44 \text { f, (ok. } 170 \mathrm{~m} \text { a.s.l.) }\end{array}$ & 19.09 .2017 & $>1$ & $\begin{array}{l}15,2621 \\
51,3376\end{array}$ & B \\
\hline $\begin{array}{l}\text { Forest District Ruszów, Forest Sub-District Dzików } \\
\text { comp. } 567 \mathrm{~g}, 567 \mathrm{f} \text {, (approx. } 160 \mathrm{~m} \text { a.s.1.) }\end{array}$ & 19.09 .2017 & 213 & $\begin{array}{l}15,1088 \\
51,3446\end{array}$ & $\mathrm{C}$ \\
\hline $\begin{array}{l}\text { Forest District Ruszów, Forest Sub-District Okrąglica } \\
\text { comp. } 106 \text { h, (approx. } 170 \text { m a.s.l.) }\end{array}$ & 19.09 .2017 & $>1$ & $\begin{array}{l}15,1649 \\
51,4190\end{array}$ & B \\
\hline $\begin{array}{l}\text { Forest District Pieńsk, Forest Sub-District Dłużyna, } \\
\text { comp. } 267 \mathrm{~g}, 268 \mathrm{~d} \text {, (approx. ok. } 190 \mathrm{~m} \text { a.s.l.) }\end{array}$ & 31.08 .2017 & $>1$ & $\begin{array}{l}15,1663 \\
51,2447\end{array}$ & B \\
\hline $\begin{array}{l}\text { Forest District Pieńsk, Forest Sub-District Stojanów, } \\
\text { comp. } 188 \mathrm{~h},(200 \mathrm{~m} \text { a.s.l.) }\end{array}$ & 31.08 .2017 & $>1$ & $\begin{array}{l}15,0996 \\
51,2891\end{array}$ & B \\
\hline $\begin{array}{l}\text { Forest District Pieńsk, Forest Sub-District Piaseczno, } \\
\text { comp. 3a, (approx. } 160 \text { m a.s.l.) }\end{array}$ & 31.08 .2017 & $>1$ & $\begin{array}{l}15,2535 \\
51,3539\end{array}$ & B \\
\hline
\end{tabular}

* Examination method: A - traps with pheromone Amitinuswit, B - examination of infested Scots pine wood, C - wood infestation observed under laboratory conditions.

\section{Gnathotrichus materiarius external morphology}

Classification to the genus Gnathotrichus and the Corthylini tribe is determined by the prothorax arching, the peak of which lies in the front part (in front of the center) (Pfeffer 1994). The species of the genus Pityophthorus can be distinguished based on: 1) smaller body size, 2) indentations on antennal clubs, 3) in females, frons covered with brush of light hairs.

Gnathotrichus materiarius. Body: black, brown translucent, shiny, slightly punctuated, glossy legs, an- tennae and mouth parts brown-yellow. Elytral declivity with shallow, broad groove along median suture. Hind margin of elytrae slightly raised. Elytral declivity with sparse, long rufous hairs (Fig. 2). From the bottom, the body is covered with golden hairs that fold down to the back of the body. On the sterna, the hairs are clearly longer, arranged in one row located in the middle part of each sternum; the entire surface of the sterna is covered with shorter hairs. On the last sternum, the hairs are positioned towards the top of the elytra. 

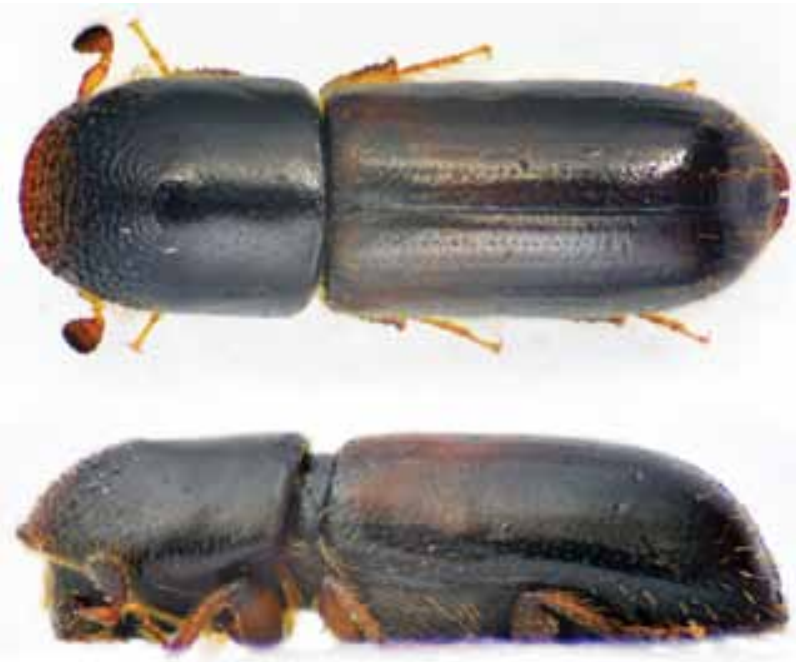

Figure 2. Gnatohrichus materiarius: top and side views (photo R. Witkowski)
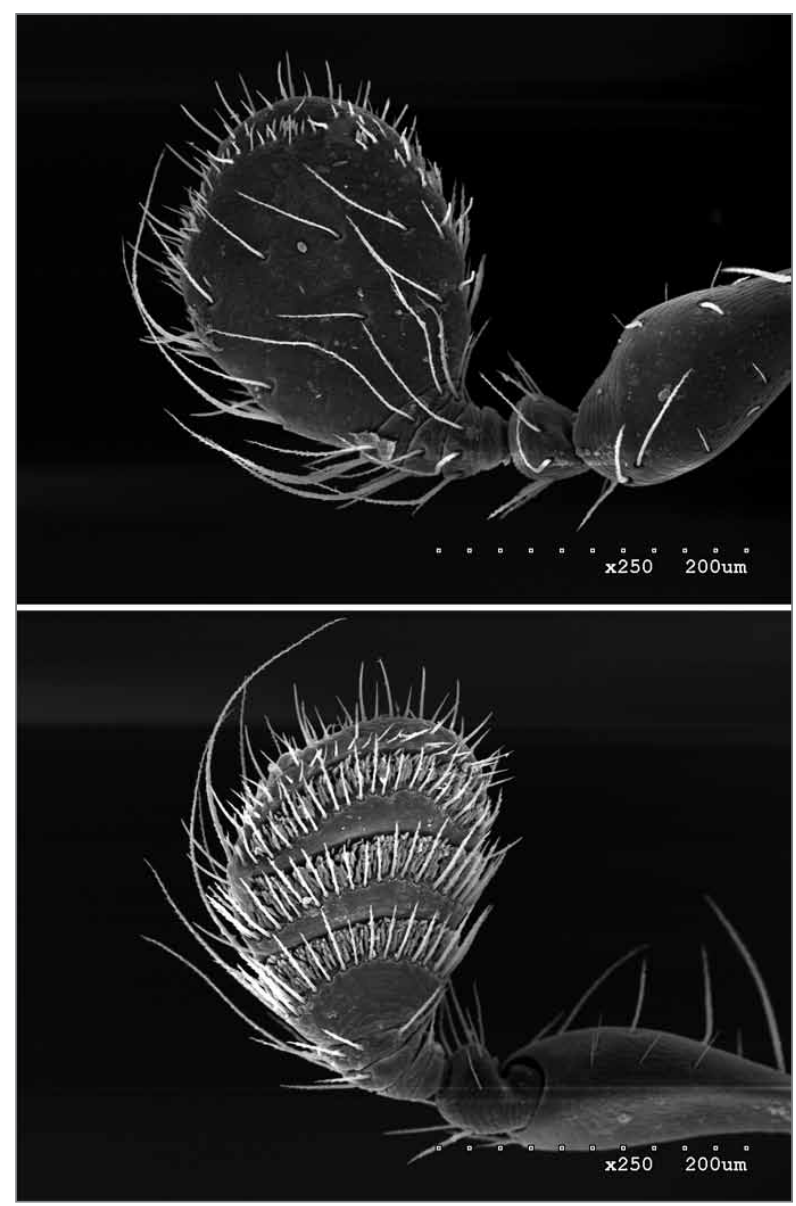

Figure 3. Gnathotrichus materiarius: female antennae, outer side and inner side of the club with septum (photo: M. Gawlak)
Sexual dimorphism is reflected by external features of antennae. Antennae with an irregular club with 3. septums; in the female on the outer edge of the club there protrude long bristles; in males there are no long bristles (Fig. 3, 4).

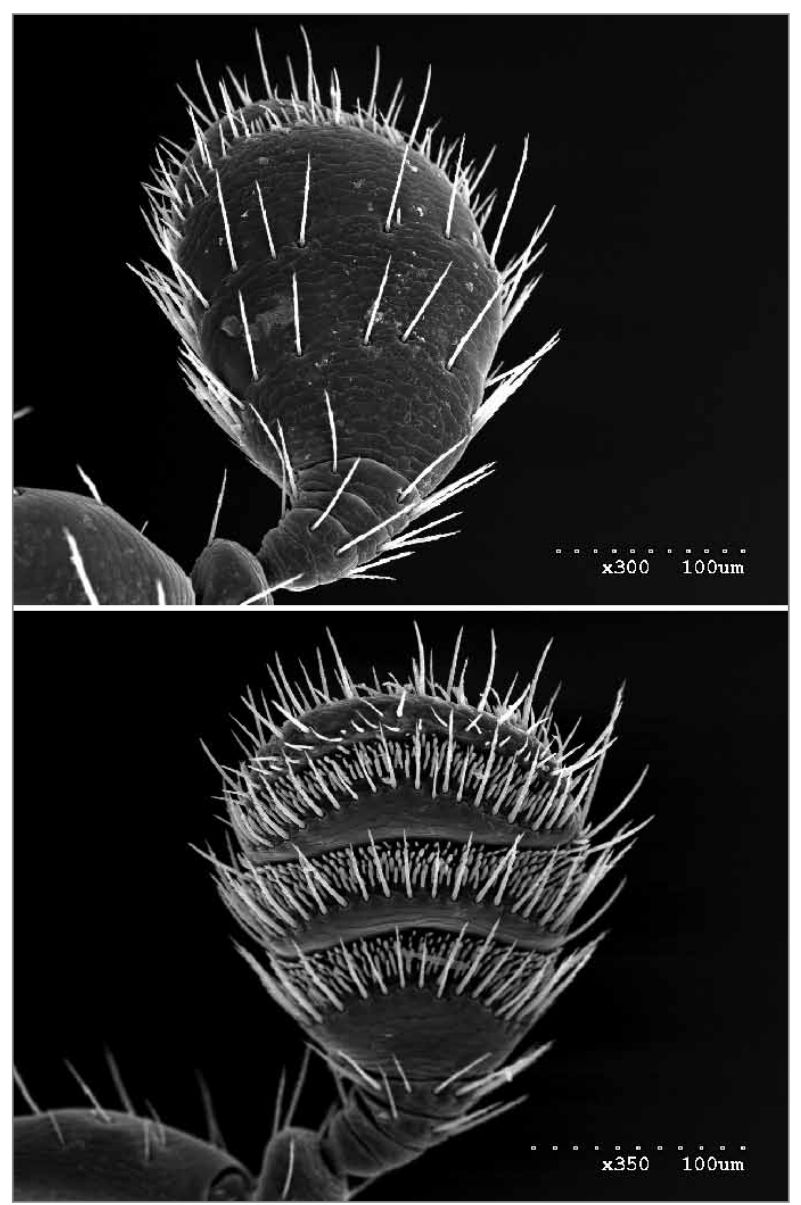

Figure 4. Gnathotrichus materiarius: male antennae, outer side and inner side of the club with septum (photo: M. Gawlak)

The average body size of ambrosia beetles from the observed population $(\mathrm{n}=24)$ is as follows: the length $-3.06 \mathrm{~mm}$ (SD $\sigma=0.07$ ), the width of prothorax base (treated as the width of the cylindrical body of the beetle) $-0.96 \mathrm{~mm}(\sigma=0.03)$, the height (measured from the side in the base of the elytra) $-0.84 \mathrm{~mm}$ $(\sigma=0.16)$.

The ratio of females to males is $1: 1.13(n=213)$. 


\section{Characteristics of feeding galleries}

Ambrosia beetles excavate the system of galleries in wood, reminiscent of the galleries made by $T$. linneatum. The gallery system consists of entrance and larvae galleries. The entrance galleries run in a radial or tangential direction from the wood surface, then branch out and run along wood annual increments (Fig. 5A). In the ends of entrance galleries, there radiate larval tunnels. The larval galleries are arranged in one plane, assuming the shape of perpendicular branches arranged in the shape of a "ladder" (Fig. 5B).

The results of gallery measurements are presented in Table 2.
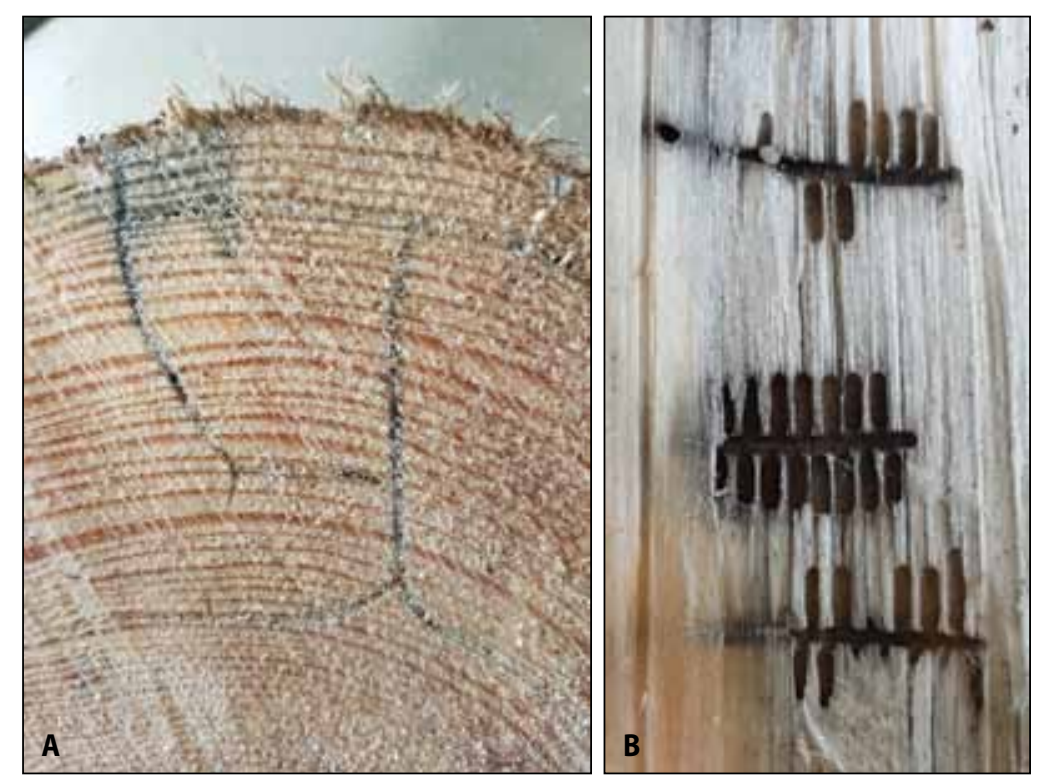

Figure 5. Gnathotrichus materiarius: A - entrance galleries on the cross-section of wood, B - "ladder" shaped larval galleries on the tangential section of wood (photo G. Rogowski)
Table 2. Metric parameters of Gnathotrichus materiarius galleries (data from the Forest District Ruszów, Sub-District Dzików, compartments 567g and 567f)

\begin{tabular}{|c|c|c|c|c|c|}
\hline Parameter & 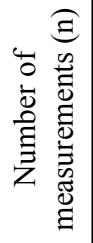 & $\begin{array}{l}\text { Mean } \\
{[\mathrm{mm}]}\end{array}$ & $\begin{array}{l}\text { Max. } \\
\text { value } \\
{[\mathrm{mm}]}\end{array}$ & $\begin{array}{l}\text { Min. } \\
\text { value } \\
{[\mathrm{mm}]}\end{array}$ & $\begin{array}{l}\text { SD } \\
(\sigma)\end{array}$ \\
\hline $\begin{array}{l}\text { Entrance hole } \\
\text { diameter }\end{array}$ & 5 & 1.05 & 1.23 & 0.84 & 0.15 \\
\hline $\begin{array}{l}\text { Diameter of entrance } \\
\text { holes }\end{array}$ & 27 & 1.02 & 1.27 & 0.6 & 0.17 \\
\hline $\begin{array}{l}\text { Entrance gallery } \\
\text { length }\end{array}$ & 11 & 15.78 & 65.78 & 4.06 & 19.18 \\
\hline Larval gallery width & 14 & 1.27 & 1.42 & 1.07 & 0.12 \\
\hline Larval gallery length & 14 & 4.27 & 5.94 & 3.69 & 0.55 \\
\hline $\begin{array}{l}\text { Distance between } \\
\text { larval galleries }\end{array}$ & 14 & 0.86 & 2.97 & 0.33 & 0.73 \\
\hline $\begin{array}{l}\text { Density: } \\
\text { Gallery length } / \mathrm{dcm}^{2}\end{array}$ & 4 & 39.4 & 61.53 & 3.77 & 35.21 \\
\hline $\begin{array}{l}\text { Density: } \\
\text { Entrance hole } \\
\text { number/dcm² }\end{array}$ & 5 & 4.85 & 6.11 & 3.68 & 0.91 \\
\hline
\end{tabular}

\section{Discussion}

G. materiarius has invaded all countries of western and central Europe and southern Scandinavia (Hirscheydt 1992, Valkama et al. 1998) ever since this ambrosia beetle was first recorded on the continent (on Pinus silvestris bark in northern France (Seine-Inférieure now Saine Maritime) (Balachowsky 1949). So far recorded localizations of its occurrence in Europe have not gone beyond the line: Finland, Western Poland, Western Bohemia, Austria, Slovenia (Valkama et al. 1998; Gillerfors 1988; Jurc et al. 2012). The localizations situated the closest to Poland's borders lie in the territories of Germany and the Czech Republic (Lorenz 2005; Knížek 2009). In Germany, G. materiarius has been recorded all through the country, with the exception of Brandenburg. Numerous localizations of occurrence have been recorded in the Middle Rhine Valley (Baden-Württemberg) and in the north of the country (Mecklenburg). G. materiarius was also observed along German-Czech border (Szumawa/Bavarian Forest and Rudawy) (Bleich et al. 2018), including Czech Republic territory (near Horšovský Týn (Knížek 2009). Closest to Polish border places of occurrence of G. materiarius in Germany are placed in Saxony (Lorenz 2005). 
In Poland, G. materiarius was firstly found in pheromone-baited traps traps for genus Ips spp., and this is consistent with observations from neighboring countries (Schneider 1985; Faccoli 1998; Valkama et al. 1998; Knižek 2009). The list of host plants includes conifers from the genera: Picea, Pinus, Larix, Tsuga, Thuja, Pseudotsuga (Hirschheydt 1992). Hence, it is obvious that pine wood can be infested by this species. However, it was only in 2017 that G. materiarius population spread out so much that numerous beetles inhabiting the raw material in the environment were observed.

Schedl (1931) provided a detailed description of the morphology of beetles of the genus Gnathotrichus Eichh. The morphology of G. materiarius was described by Wood (1982), and further presented by Postner (1974), López et al. (2007), Grodzki and Mokrzycki (2014), Mokrzycki (2016) and Witkowski et al. (2016). Notwithstanding Pfeffer (1994) and López et al. (2007), there is a lack of keys in taxonomic papers for the identification of european bark beetles to the genus and species beetles from Corthylini, including G. materiarius.

It is difficult to determine a sex of $G$. materiarius specimens based on differences in the antenna morphology. This requires good optical equipment and properly prepared beetles. The sex ratio in the population of $G$. materiarius provides information for explanation of the life strategy of the species. Postner (1974) states that the galleries are axcavated by males, and their share in the population is small when compared to female which indicates polygamy and at the same time, the number of males can be a factor limiting fertility. However, in the observed $G$. materiarius population from the Forest District Ruszów, the male and female numbers were similar, which means that the sex ratio may fluctuate in the short or long term.

\section{Conclusions}

During just two years of not targeted observations, there was recorded an increase in the number and concentration of G. materiarius occurrences in the Forest Districts: Ruszów, Węgliniec and Pieńsk (western Poland), as well as in the Forest Districts Świeradów and Kamienna Góra and the National Parks: Karkonoski and Góry Stołowe (south of the country). These localizations con- firm the spread of the species in Central Europe towards the east. In Poland G. materiarius infestation of Scots pine wood has been for the first time observed in managed forests. The scale of the phenomenon is currently of no economic importance, but assuming that the species will be spreading out, its importance as a technical wood pest will/may be comparable to the importance of Trypodendron lineatum (Oliv.).

\section{Acknowledgements}

Scanning photos of beetle antennae were prepared by Magdalena Gawlak in the Research Centre for Quarantine, Invasive and Genetically Modified Organisms at the Institute of Plant Protection - National Research Institute in Poznań, Poland

We would like to thank the Forestry Officers from the Forest Districts Ruszów, Węgliniec and Pieńsk for help during field inspections, as well as all persons who inspected pheromone-baited traps against spruce bark beetles mounted in the Forest Districts studied.

\section{References}

Balachowsky, A. 1949. Faune de France. 50. Coléopteres Scolytides, Paris.

Bark Beetle Genera of the United States. 2011. Available at http://idtools.org/id/wbb/bbgus/factsheet. php?name $=14465$.

Bleich, O., Gürlich, S., Köhler, F. 2018. Verzeichnis und Verbreitungsatlas der Käfer Deutschlands. Available at www.coleokat.de (access on 14.03.2018).

Faccoli, M. 1998. The North American Gnathotrichus materiarius (Fitch) (Coleoptera Scolytidae): an ambrosia beetle new to Italy. Redia, 81, 151-154.

Gillerfors, G. 1988. Skalbaggar införda till Sveringe med importerad massaved. Entomologisk Tidskrift, 9, 42-45.

Grodzki, W., Mokrzycki, T. 2014. Drzewotocz japoński - Xylosandrus germanus (Bldf.) i inne nowe gatunki korników w faunie Polski - występowanie i potencjalne zagrożenia dla drzewostanów. Biblioteczka Leśniczego, 364, 3-15.

Hirschheydt, J. von 1992. Der Amerikanische Nutzholzborkenkäfer Gnathotrichus materiarius 
(Fitch) hat der Schweiz erreicht. Mitteilungen der Schweizerischen Entomologischen Gesellschaft, $65,33-37$.

Jurc, M., Bojovic, S., Fernández, M.F., Jurc, D. 2012. The attraction of cerambycids and other xylophagous beetles, potential vectors of Bursaphelenchus xylophilus, to semio-chemicals in Slovenia. Phytoparasitica, 40 (4), 337-349.

Knížek, M. 2009. Faunistic records from the Czech Republic - 272. Coleoptera: Curculionidae: Scolytinae. Klapalekiana, 45, 22.

López, S., Iturrondobeitia, J.C., Goldarazena, A. 2007. Primera cita en la Península Ibérica de Gnathotrichus materiarius (Fitch, 1858) y Xylosandrus germanus (Blandford, 1894) (Coleoptera: Scolytinae). Boletín Sociedad Entomologica Aragonesa, 40, 527-532.

Lorenz, J. 2005. Neu- und Wiederfunde von Käferarten (Col.) für die Fauna Sachsens sowie weitere faunistisch bemerkenswerte Käfernachweise 2001-2005. Entomologische Nachrichten und Berichte, 49, 195-202.

Mazur, A., Witkowski, R., Góral, J., Nowik, K., Skałecka, K., Rogowski, G. 2017. Monitoring kornika drukarczyka (Ips amitinus Eichh.) na terenie RDLP Wrocław. In: Current Problems of Forest Protection - 2017 Wałcz 2-5 October 2017 (eds.: I. Skrzecz, L. Sukovata). Abstract book 21.

Mokrzycki, T., Hilszczański J., Borowski, J., Cieślak, R., Mazur, A., Miłkowski, M., Szołtys, H. 2011. Faunistic review of Polish Platypodinae and Scolytinae (Coleoptera: Curculionidae). Polish Journal of Entomology, 80, 343-364. DOI: 10.2478/ v10200-011-0024-1.

Otto, L.F., Rödiger, K., Matschulla, F., Góral, J., Nowik, K., Skałecka, K., Rogowski, G., Witkowski, R., Mazur, A. 2016. Monitoring kornika zrosłozębnego (Ips duplicatus Sahlb.) w Saksonii, Sudetach i na Dolnym Śląsku. In: Aktualne problemy ochrony lasu - 2016. Międzynarodowa konferencja naukowa organizowana przez Komisję Zasobów leśnych PTL, IBL i RDLP w Poznaniu, Będlewo 17-20 października 2016.

Pfeffer, A. 1994. Zentral- und Westpaläarktische Borken- und Kernkäfer (Coleoptera, Scolytidae, Platypodidae). Entomologica Basiliensa, 17, 5-310.

Postner, M. 1974. Scolytidae Borkenkäfer. In: Die Forstschädlinge Europas. Bd 2. Käfer (ed.: W. Schwenke), 334-482. Paul Parey, Hamburg, Berlin.

Schedl, K.E. 1931. Morphology od the bark-beetles of the genus Gnathotrichus Eichh. Smithsonian Miscellaneous Collections, 82 (10), 1-84.

Schedl, K.E. 1980. Catalogus Faunae Austriae, XV: Coleoptera, Scolytidae und Platypodidae. Österreichische Akadaemie der Wissenschaften, Wien.

Schneider, I. 1985. Gnathotrichus materiarius Fitch (Col., Scolytidae) in Pheromonfallen von Ips cembrae (Heer) (Col., Scolytidae) ein neuer Fundort für NW-Deutschland. Anzeiger für Schädlingskunde, Phflanzenschutz, Umweltschutz, 58, 50-51.

Valkama, H., Martikainen, P., Räty, M. 1998. First record of North American ambrosia beetle Gnathotrichus materiarius (Fitch) (Coleoptera, Scolytidae) in Finland - a new potential forest pest? Entomologica Fennica, 8, 193-195.

Wanat, M., Mokrzycki, T. 2018. The checklist of the weevils (Coleoptera: Curculionoidea) of Poland revisited. Annales Zoologici, 68 (1), 1-48.

Witkowski, R., Góral, J., Nowik, K., Rogowski, G., Skałecka, K., Mazur, A. 2016. Gnathotrichus materiarius (Fitch, 1858) (Coleoptera: Curculionidae, Scolytinae) - new species of beetle in the Polish fauna. Acta Scientiarum Polonorum Silvarum Colendarum Ratio et Industria Lignaria, 15 (1), 43-47. DOI: 10.17306/J.AFW.2016.1.6

Wood, S.L. 1982. The bark and ambrosia beetles of North and Central America (Coleoptera Scolytidae), a taxonomic monograph. Great Basin Naturalist Memoirs, 6, 1-1359.

Wood, S.L., Bright, D.E. 1992. A Catalog of Scolytidae and Platypodidae (Coleoptera), Part 2: Taxonomic Index. Volume B. Great Basin Naturalist Memoirs, $13,1-1557$. 